\title{
Non-additive effects of ocean acidification in combination with warming on the larval proteome of the Pacific oyster, Crassostrea gigas
}

\author{
Harney Ewan ${ }^{1,{ }^{*}}$, Artigaud Sébastien ${ }^{1}$, Le Souchu Pierrick ${ }^{2}$, Miner Philippe ${ }^{2}$, Corporeau Charlotte ${ }^{2}$, \\ Essid Hafida ${ }^{1}$, Pichereau Vianney ${ }^{1}$, Nunes Flavia L.D. ${ }^{1}$
}

${ }^{1}$ Laboratoire des Sciences de I'Environnement Marin (LEMAR), UMR 6539CNRS/UBO/IRD//fremer, Institut Universitaire Européen de la Mer, University of Brest (UBO), Université Européenne de Bretagne (UEB), Place Nicolas Copernic, 29280 Plouzané, France

${ }^{2}$ Ifremer, Laboratoire des Sciences de l'Environnement Marin (LEMAR), UMR 6539CNRS/UBO/IRD/Ifremer, Centre Bretagne Z.I. Pointe du Diable, 29280 Plouzané, France

* Corresponding author : Ewan Harney, ewan.harney@univ-brest.fr

\begin{abstract}
:
Increasing atmospheric carbon dioxide results in ocean acidification and warming, significantly impacting marine invertebrate larvae development. We investigated how ocean acidification in combination with warming affected D-veliger larvae of the Pacific oyster Crassostrea gigas. Larvae were reared for $40 \mathrm{~h}$ under either control $\left(\mathrm{pH} 8.1,20^{\circ} \mathrm{C}\right)$, acidified $\left(\mathrm{pH} 7.9,20^{\circ} \mathrm{C}\right)$, warm $\left(\mathrm{pH} 8.1,22^{\circ} \mathrm{C}\right)$ or warm acidified ( $\left.\mathrm{pH} 7.9,20^{\circ} \mathrm{C}\right)$ conditions. Larvae in acidified conditions were significantly smaller than in the control, but warm acidified conditions mitigated negative effects on size, and increased calcification. A proteomic approach employing two-dimensional electrophoresis (2-DE) was used to quantify proteins and relate their abundance to phenotypic traits. In total 12 differentially abundant spots were identified by nano-liquid chromatography-tandem mass spectrometry. These proteins had roles in metabolism, intra- and extra-cellular matrix formations, stress response, and as molecular chaperones. Seven spots responded to reduced $\mathrm{pH}$, four to increased temperature, and six to acidification and warming. Reduced abundance of proteins such as ATP synthase, GAPDH and increase of superoxide dismutase occurred when both $\mathrm{pH}$ and temperature changes were imposed, suggesting altered metabolism and enhanced oxidative stress. These results identify key proteins that may be involved in the acclimation of $C$. gigas larvae to ocean acidification and warming.
\end{abstract}

\section{Significance}

Increasing atmospheric $\mathrm{CO}_{2}$ raises sea surface temperatures and results in ocean acidification, two climatic variables known to impact marine organisms. Larvae of calcifying species may be particularly at risk to such changing environmental conditions. The Pacific oyster Crassostrea gigas is ecologically and commercially important, and understanding its ability to acclimate to climate change will help to predict how aquaculture of this species is likely to be impacted. Modest, yet realistic changes in $\mathrm{pH}$ and/or temperature may be more informative of how populations will respond to contemporary climate change. We showed that concurrent acidification and warming mitigates the negative effects of $\mathrm{pH}$ alone on size 
of larvae, but proteomic analysis reveals altered patterns of metabolism and an increase in oxidative stress suggesting non-additive effects of the interaction between $\mathrm{pH}$ and temperature on protein abundance. Thus, even small changes in climate may influence development, with potential consequences later in life.

\section{Graphical abstract}

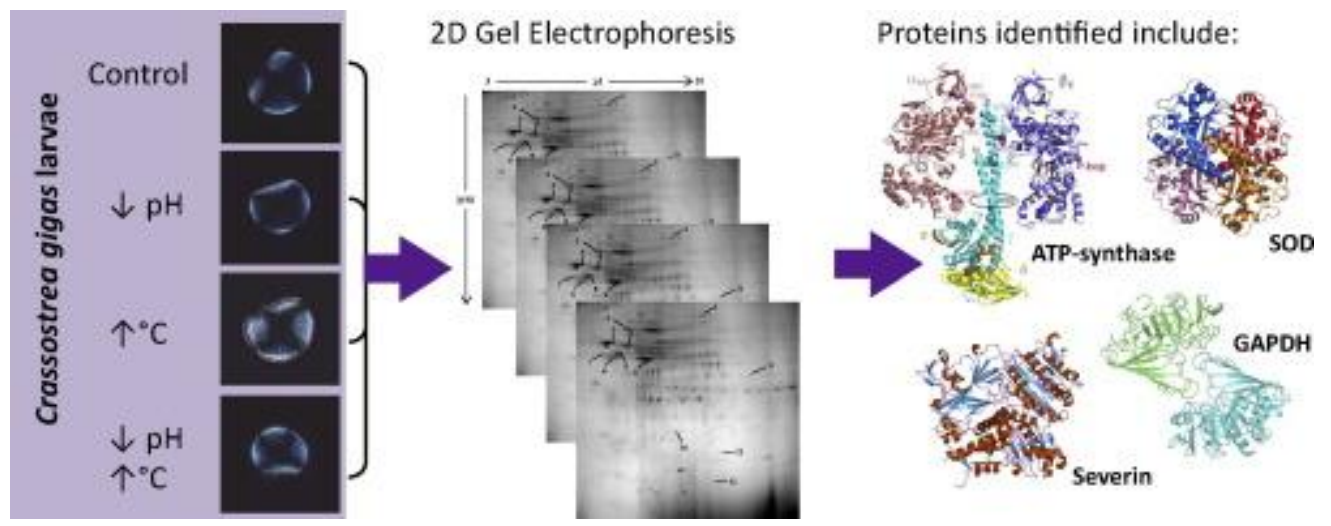

\section{Highlights}

High temperature offsets negative phenotypic consequences of acidification. Twelve protein spots were associated with response to $\mathrm{pH}$ and/or temperature. Metabolic, matrix forming, stress, and molecular chaperone proteins were identified. At low $\mathrm{pH}$ and high temperature ATP-synthase and GAPDH were reduced, SOD increased. Changes suggest metabolic shift from catabolism to anabolism and response to ROS.

Keywords: Crassostrea gigas, Ocean acidification, Larval development, ATP synthase, GAPDH, Superoxide dismutase

\section{Introduction}

Today's oceans are undergoing widespread alteration as a result of the changing global climate [1]. Elevated atmospheric $\mathrm{CO} 2$ leads to increasing sea surface temperatures [2] and acidification of marine environments [3,4], with the oceans acting as a sink for more than a third of all anthropogenic carbon emissions [5]. End-of-the-century projections for atmospheric pCO2 range from 600 to $1000 \mathrm{ppm}$ (corresponding roughly to a decrease of $0.2-0.5 \mathrm{pH}$ units) and an increase in sea surface temperatures of $0.6^{\circ} \mathrm{C}$ to $2.0^{\circ} \mathrm{C}$, depending on the scenario adopted [1]. A direct consequence of this ocean acidification $(\mathrm{OA})$ will be a reduction in the saturation state for carbonate ions [6], which will make the calcification mechanisms employed by many marine organisms more energetically costly [7], potentially putting them at a disadvantage compared to organisms that do not produce calcified structures [8]. Concurrent warming and acidification can result in synergistic negative effects on calcification [9] and other biological processes, although responses are likely to vary between taxa. 
Larval stages of molluscs may be particularly at risk of acidification in warming marine environments [10], as their shells are extremely fragile [11], and the high rate of biocalcification required to form early skeletal structures makes them highly sensitive to reductions in the saturation state of carbonate ions [12]. The effects of changing environmental conditions on larvae are important to understand as these early life stages often represent a bottleneck for populations struggling to survive in the changing marine environment $[13,14]$. Reductions of $0.5 \mathrm{pH}$ units often results in reduced survival of marine molluscs, as shown for Mercenaria mercenaria, Argopecten irradians [15] and Crassostrea gigas [16], while a $\mathrm{pH}$ decrease of 0.7 units can lead to abnormal development and high levels of mortality, as shown in C. gigas [17] and Mytilus galloprovincialis [18]. Increasing temperatures compound problems caused by acidification, increasing mortality and rates of abnormality and reducing size when both are considered concurrently, as shown in both the Sydney rock oyster Saccostrea glomerata [19] and C. gigas [20] during the first 48 hours of development.

Prolonged exposure to $\mathrm{pH}$ reductions of $05-0.7 \mathrm{pH}$ units will likely elicit strong stress responses in many organisms [for a review, see 20], but reductions in $\mathrm{pH}$ by $0.2-0.3 \mathrm{pH}$ units (corresponding to future $p \mathrm{CO}_{2}$ levels of $600-750 \mathrm{ppm}$ ) are considered more useful for understanding how organisms will respond to future changes in $\mathrm{pH}$, according to the European Commission's Guide for best practices for ocean acidification research [22]. Although populations will typically have many generations to adapt to these average changes in $\mathrm{pH}$ and temperature [23], coastal ecosystems also demonstrate temporal and regional variation in $\mathrm{pH}$ and temperature meaning many populations already face conditions predicted for the end-of-the-century at certain points in time or in parts of their range [24]. Therefore identifying how organisms acclimate to these changes is a crucial step in understanding how populations might respond to global climate change. Even small changes in $\mathrm{pH}$ can influence 
growth and development: a reduction of $0.2 \mathrm{pH}$ units resulted in significantly slower growth in both $C$. gigas and the Sydney rock oyster Saccostrea glomerata during the first 48 hours of development [20], while a reduction of $0.3 \mathrm{pH}$ units reduced growth and calcification in $C$. gigas during the first three days of development [25]. On the other hand, small increases in temperature may result in faster rates of growth and development, offsetting negative effects of acidification [26-28]. Differences in growth and the timing of development may have important consequences for population dynamics and demography [29], and developmental plasticity is a key source of variation in adult phenotypes, directly influencing evolution of populations and species [30,31]. For these reasons, investigation of smaller changes in $\mathrm{pH}$ over single generations may provide a more realistic indication of how organisms will respond to ocean acidification.

As well as directly investigating the effects of environmental change on the developmental plasticity of phenotypes, it is now possible to use molecular '-omics' approaches to reveal the molecular signals underlying the response of development traits to small changes in $\mathrm{pH}$ and temperature, even when there are few outward signs of phenotypic change [32]. Proteomic techniques such as two-dimensional gel electrophoresis (2-DE) can help to identify the mechanisms underlying developmental plasticity [33] without a priori expectations. Identification of differentially accumulated proteins highlights potential candidates involved in acclimatory or adaptive responses. In this study we characterise the effects of acidification and warming, both separately and together, on protein abundance in larvae of the Pacific oyster $C$. gigas 40 hours post-fertilisation, at which point the vast majority of larvae have reached veliger stage and are calcifying [25]. C. gigas is a bivalve of commercial significance and is also an important ecosystem engineer [34]. The 2-DE methodology presented has already been validated in organs [35,36] as well as in oocytes of this species [37], and is used here to identify major changes in abundant and soluble larval proteins in response to near 
future change in $\mathrm{pH}$ and temperature, in order to identify key proteins involved in developmentally plastic phenotypes.

\section{Materials and methods}

\section{Conditioning of adults and larval rearing}

Thirty mature Crassostrea gigas aged two years were transferred to the Ifremer laboratory in Plouzané, France, in July 2013 and were kept, unfed, in constantly flowing filtered sterile sea water (FSSW) from the bay of Brest at $19.7 \pm 0.3^{\circ} \mathrm{C}$ and $\mathrm{pH} 8.07 \pm 0.04$ units (reflective of natural conditions for the time of year) for 5 weeks prior to the spawning. Sex was determined under a light microscope and fertilisation was carried out with oocytes from five females combined and fertilized with the sperm from four males, and following a standard protocol [38]. Oocytes and sperm were periodically mixed, and after 90 minutes eggs were split equally among 12 open-flow 5L tanks in one of four treatments (3 replicates per treatment): 'control' (median temperature and median $\mathrm{pH} \pm$ upper/lower bound $=19.9 \pm$ $\left.0.4^{\circ} \mathrm{C}, \mathrm{pH} 8.06 \pm 0.06\right),{ }^{\prime}$ acidified' $\left(19.8 \pm 0.3^{\circ} \mathrm{C}, \mathrm{pH} 7.87 \pm 0.05\right)$, 'warm' $\left(21.7 \pm 0.5^{\circ} \mathrm{C}, \mathrm{pH}\right.$ $8.09 \pm 0.05)$ and 'warm acidified' $\left(21.8 \pm 0.5^{\circ} \mathrm{C}, \mathrm{pH} 7.87 \pm 0.03\right)$. To create these conditions, a large header tank (100L) was filled with filtered and UV-sterilised sea water that had been warmed to $22^{\circ} \mathrm{C}$. This water was then pumped directly to the three 'warm' treatment tanks and to two other header tanks (50L), one in which water was cooled to $20^{\circ} \mathrm{C}$ via heat exchange, the other in which $\mathrm{pH}$ was reduced by bubbling $\mathrm{CO}_{2}$ through a $\mathrm{CO}_{2}$ reactor (JBL GmbH \& Co. KG, Neuhofen, Germany), maintained by negative feedback. These header tanks pumped water to the three 'control' and three 'warm acidified' treatments tanks respectively. Finally water from the 'warm acidified' header tank was also pumped to a fourth header tank (50L) where the water was cooled to $20^{\circ} \mathrm{C}$ by a second heat exchange, 
before being pumped to the three 'acidified' treatment tanks. Flow rate to experimental tanks was maintained at $80 \mathrm{ml} \mathrm{min}^{-1}$, and the outflow passed through a $20 \mu \mathrm{m}$ mesh filter to keep larvae in tanks. Larvae were kept in suspension and free from outflow filters by constantly bubbling air from the bottom of the tanks over the filters. An overview of the installation is shown in Supplementary Figure 1. Temperature and $\mathrm{pH}$ in each treatment tank were measured at four times during the 40-hour experiment using a WTW pH 340i fitted with a WTW SenTix 41 pH electrode (WTW GmbH, Weilheim, Germany); total alkalinity was determined from bicarbonate titration of triplicated samples collected at three times from a large header tank (analyses performed by Labocea laboratories, Brest, France); and salinity measurements were taken before and after the experiment using a WTW LF 340-B conductivity salinometer (WTW GmbH, Weilheim, Germany). Values for dissolved inorganic carbon, partial pressure of carbon dioxide, concentrations of bicarbonate and carbonate ions, and saturation states of calcite and aragonite were calculated using the $\mathrm{CO}_{2} \mathrm{SYS}$ program [39] based on constants from Cai and Wang [40] fitted to the Total $\mathrm{pH}$ scale; mean conditions during the experiment are presented in Supplementary table 1.

Larvae were allowed to develop for 40 hours post-fertilisation before counts and sampling, because preliminary experiments showed that in all treatments, only D-larvae were present in experimental tanks at this time. For morphological measurements, approximately 10000 individuals were collected by passing FSSW through a 40 $\mu \mathrm{m}$ mesh, and aspirating the larvae into a tube containing $1 \mathrm{ml}$ of absolute ethanol:phosphate buffered saline (PBS) solution 1:1 (v/v). After four days at $4^{\circ} \mathrm{C}$, samples were transferred to a $70 \%$ ethanol solution and stored at $4^{\circ} \mathrm{C}$. For protein analysis, approximately 4 litres of water from each tank were passed through a $40 \mu \mathrm{m}$ mesh, and the remaining larvae (mean \pm SE estimated at $160000 \pm 16000$ per tank) were recovered into $2 \mathrm{ml}$ tubes with the minimal amount of sea water possible $(<1 \mathrm{ml})$ to 
minimise salting-out of proteins during lysis [37]. One $\mathrm{ml}$ of lysis buffer [41] was added to the tube and samples were snap frozen in liquid nitrogen and stored at $-80^{\circ} \mathrm{C}$ until extraction.

\section{Phenotypic measurements}

A small volume of larvae from the $70 \%$ ethanol solution was added to a glass slide and immersed in glycerol. Larvae were viewed on an Olympus BX60 microscope fitted with an Olympus U-CMAD3 camera. For each flute, 30-50 D-larvae were photographed under a fixed illumination of both white and polarising light at $20 \times$ magnification, and images were captured with analySIS start software (Olympus). Polarised light is refracted twice when passing through calcium carbonate, and the intensity of birefringence following double refraction provides a proxy for calcification. Size and birefringence measurements were assessed using imageJ software [42]. Size was calculated as area in $\mu \mathrm{m}^{2}$, while birefringence was quantified as a greyscale score for polarised light images on a scale of 0-255 [43].

Checks for normality and homoscedasticity using Shapiro and Levene tests revealed that size data were non-normally distributed, and birefringence data were non-normally distributed and heteroscedastic. Therefore non-parametric Kruskal-Wallis tests followed by Bonferronicorrected Dunn post-hoc tests were carried out to analyse differences between treatment groups. Dunn tests assume that cumulative distribution functions of treatment groups do not cross [44]. In order to meet this assumption, outlying birefringence samples (greyscale scores $>1.5$ interquartile ranges beyond the $1^{\text {st }}$ or $3^{\text {rd }}$ quartile) were removed. All analyses were carried out using the dunn.test package [44] in $R$ [45]. 
Total protein extraction was performed on samples of larvae homogenized with a Polytron® PT $2500 \mathrm{E}$ (Kinemetica, Lucerne, Switzerland) at $4^{\circ} \mathrm{C}$ in $2 \mathrm{~mL}$ of lysis buffer $(150 \mathrm{mM} \mathrm{NaCl}$, $10 \mathrm{mM}$ Tris $\mathrm{pH}$ 7.4, 1 mM EDTA, 1 mM EGTA, 1\% Triton X-100, and 0.5\% Igepal; pH 8.8 at $\left.4^{\circ} \mathrm{C}\right)$ containing phosphatase and protease inhibitors $(1 \%$ of Phosphatase inhibitor cocktail II [Sigma-Aldrich], $2 \%$ of NaPPi $250 \mathrm{mM}$, and 1 tablet of complete EDTA free protease inhibitor cocktail [Roche] in $25 \mathrm{~mL}$ of lysis buffer)[41]. Solubilized proteins were extracted by centrifugations at $4,000 \mathrm{~g}$ for $1 \mathrm{~h}$ at $4^{\circ} \mathrm{C}$. The lipid layer was in the upper phase and was easily eliminated by pipetting. The interphase (around $1.5 \mathrm{ml}$ ) containing the proteins was collected and the small pellet of cell debris was left. The phase containing proteins was then centrifuged at $10,000 \mathrm{~g}$ for $45 \mathrm{~min}$ at $4{ }^{\circ} \mathrm{C}$ to ensure total lipid depletion. The resulting lysates were aliquoted and stored at $-80^{\circ} \mathrm{C}$ for further analysis. Protein lysates were quantified using a $\mathrm{D}_{\mathrm{C}}$ protein assay (Bio-Rad, Hercules, CA, USA) with 96-well micro-plates $\left(\mathrm{Nunc}^{\mathrm{TM}}\right.$ ) in a micro-plate reader (Bio-Tek® SynergyTM HT) and KC4 v3 software to compare results with a calibration curve of standard proteins (Bovine Serum Albumin) provided with the $\mathrm{D}_{\mathrm{C}}$ protein assay kit. For each protein sample a Bradford assay was performed to make $500 \mu \mathrm{g}$ of protein deposition. For each of the 12 samples, precipitation and desalting were performed by adding one volume of a mixture of TCA/acetone (20\% TCA) and precipitating the proteins overnight at $-20^{\circ} \mathrm{C}$. Precipitated proteins were centrifuged at $20,000 \mathrm{~g}$ at $4^{\circ} \mathrm{C}$ for 10 minutes. After removing the supernatant, the protein pellet was neutralized 2-3 times by adding $150 \mu \mathrm{l}$ of a solution of Tris- $\mathrm{HCl} \mathrm{pH} 7.4(50 \mathrm{mM}) / 80 \%$ acetone containing traces of bromophenol blue, used herein as a $\mathrm{pH}$ indicator, followed by centrifugation at $12,000 \mathrm{~g}$ for 10 minutes. The pellets were dried using a rotary evaporator (Eppendorf concentrator 5301) at $30{ }^{\circ} \mathrm{C}$ for 10 minutes and resuspended in $250 \mu 1$ of Destreak rehydration solution (GE Healthcare), containing $1 \%$ IPG buffer ( $\mathrm{pH} 3-10)$ before being placed at room temperature for $1 \mathrm{~h}$ before isoelectric focusing (IEF). The IEF dimension was conducted on a IPGphor3 system (GE 
Healthcare) using the following protocol: $250 \mathrm{~V}$ for 15 minutes, $500 \mathrm{~V}$ for 2 hours, gradient voltage increase to $1000 \mathrm{~V}$ for 1 hour, gradient voltage increase to $8000 \mathrm{~V}$ for 2 hours and 30 minutes, and $8000 \mathrm{~V}$ for 3 hours, all carried out at $20^{\circ} \mathrm{C}$. Before the second dimension, the IPG strip was rehydrated in a solution containing $50 \mathrm{mM}$ Tris- $\mathrm{HCl} \mathrm{pH} 8.8,6 \mathrm{M}$ urea, 30\% glycerol, $2 \%$ SDS and $0.002 \%$ Bromophenol Blue for two 15 minute periods, first with 10 $\mathrm{mg} / \mathrm{ml}$ dithiothreitol, and then in the same solution containing $48 \mathrm{mg} / \mathrm{ml}$ iodoacetamide [46].

For the second dimension, each strip was deposited on the surface of a lab-cast $15 \mathrm{~cm} \times 15 \mathrm{~cm}$ SDS-PAGE gel containing $12 \%$ acrylamide, and allowed to migrate in a thermoregulated device at $10{ }^{\circ} \mathrm{C}$, as described in Artigaud et al [47]. After migration, protein spots were stained with Coomassie Blue (PhastGel, GE Healthcare) overnight, and then bleached by successive baths in a $\mathrm{H}_{2} \mathrm{O} /$ methanol/acetic acid: 70/30/7 solution. The resulting gels were photographed and observed using G:BOX (SynGene). For image analysis, 16-bit level images of the gels were captured in .tif format. Three samples per condition were analysed. Images were aligned and spots detected using Progenesis SameSpots v3.3 software (Nonlinear Dynamics, Newcastle upon Tyne, UK). All analysed protein spots were manually checked and artifact spots removed. ANOVA statistical analyses considering: i) the effect of reduced $\mathrm{pH}$ at each temperature; ii) increased temperature at each $\mathrm{pH}$; and iii) coincident reduced $\mathrm{pH}$ and increased temperature, were performed using the statisitics module of SameSpot, with a P value of 0.02 used to limit the number of false positives identified [48]. Significantly differentially expressed proteins at $\mathrm{P}<0.02$ were excised and sequenced.

\section{Mass spectrometry}

The excised spots were washed with milliQ water, destained in $100 \mathrm{mM}$ $\mathrm{NH}_{4} \mathrm{HCO}_{3}$ /acetonitrile (ACN) (1:1), and dehydrated in $100 \%$ ACN. After rehydration in 100 
$\mathrm{mM} \mathrm{NH} \mathrm{NCO}_{3}$ and dehydration in $100 \% \mathrm{ACN}$, excised spots were air-dried and incubated overnight at $37^{\circ} \mathrm{C}$ in a solution of $12.5 \mathrm{ng} / \mu \mathrm{L}$ modified trypsin (Promega) in $50 \mathrm{mM}$ $\mathrm{NH}_{4} \mathrm{HCO}_{3}$. The resulting tryptic peptides were extracted from the gel spots by several washes in formic acid/ACN/water as previously described [36]. The tryptic digests were then concentrated by vacuum centrifugation to reach a final volume of $30 \mu \mathrm{L}$. Mobile A $\left(\mathrm{H}_{2} \mathrm{O} /\right.$ formic acid, 100:0.1) and B (ACN/formic acid, 100:0.1) phases for HPLC were delivered by the Ultimate 3000 nanoflow LC system (Dionex, LC Packings). $10 \mu \mathrm{L}$ of peptide mixture was loaded on a trapping precolumn $(5 \mathrm{~mm} \times 300 \mu \mathrm{m}$ i.d., $300 \AA$ A pore size, Pepmap C18, $5 \mu \mathrm{m}$ ) for $3 \mathrm{~min}$ in $2 \%$ buffer B at a flow rate of $25 \mu \mathrm{L} / \mathrm{min}$. This step was followed by reverse-phase separations at a flow rate of $0.250 \mu \mathrm{L} / \mathrm{min}$ using an analytical column $(15 \mathrm{~cm} \times 300 \mu \mathrm{m}$ i.d., $300 \AA$ pore size, Pepmap C18, $5 \mu \mathrm{m}$, Dionex, LC Packings $)$. A gradient ranging from $2 \%$ to $35 \%$ of buffer B was run for the first 60 minutes, $35 \%$ to $60 \%$ of buffer B from $60-85$ minutes, and $60 \%$ to $90 \%$ of buffer B from $85-105$ minutes. Finally, the column was washed with $90 \%$ of B for 16 minutes, and with $2 \%$ of B for 19 minutes prior to loading of the next sample. The peptides were detected by directly eluting them from the HPLC column into the nanoelectrospray ion source of the LTQ-Orbitrap XL (ThermoScientific) mass spectrometer. An ESI voltage of $1.4 \mathrm{kV}$ was applied to the HPLC buffer using the liquid junction provided by the nanoelectrospray ion source and the ion transfer tube temperature was set to $200^{\circ} \mathrm{C}$. The LTQ-Orbitrap XL instrument was operated in its data-dependent mode by automatically switching between full survey scan MS and consecutive MS/MS acquisition. Survey full scan MS spectra (m/z 400-2000) were acquired in the OrbiTrap with a resolution of $r=60000$ at $\mathrm{m} / \mathrm{z} 400$; ion injection times are calculated for each spectrum to allow for accumulation of 106 ions in the OrbiTrap. The 10 most intense peptide ions in each survey scan with intensity above 2000 counts and a charge state $\geq 2$ were sequentially isolated and fragmented in the ion trap by collision induced dissociation. 
Normalized collision energy was set to $35 \%$ with an activation time of $30 \mathrm{~ms}$. Peaks selected for fragmentation were automatically put on a dynamic exclusion list for $60 \mathrm{~s}$ with a mass tolerance of $\pm 10 \mathrm{ppm}$.

\section{Data processing}

Mass spectrometry data were saved in RAW file format (ThermoScientific) using XCalibur 2.0.7 with tune 2.4. The data analysis was performed with the Proteome Discoverer 1.2 software supported by Mascot (Mascot server v2.2.07; http://www.matrixscience.com) database search engines for peptide and protein identification. MS/MS spectra were compared to the Crassostrea gigas Uniprot Reference Proteome database (UP000005408, July 2014, 25978 sequences, 11649621 residues). Mass tolerance for MS and MS/MS was set at $10 \mathrm{ppm}$ and $0.5 \mathrm{Da}$, respectively. Trypsin was selected as enzyme with one miscleavage allowed. Protein modifications were fixed carbamidomethylation of Cys and variable oxidation of Met. Identified peptides were filtered based on the Mascot score to obtain a false discovery rate of $1 \%$. Only rank 1 peptides were considered. In the case of peptides shared by different proteins, proteins were automatically grouped. The proteins within a group were ranked according to their protein score. The proteins reported carried the highest scores. Data are available via ProteomeXchange with identifier PXD002316. Homology searches obtained from the Crassostrea gigas Uniprot Reference Proteome database were validated or sometimes modified by carrying out a protein blast of the amino acid sequence in UniProt (http://www.uniprot.org/blast/) using standard parameters to search for the highest scoring characterised mollusc protein. 


\section{Results}

\section{Larval size and birefringence}

Temperature and $\mathrm{pH}$ treatments resulted in significant differences in size for D-larvae 40 hours post-fertilisation (Kruskal-Wallis $\chi^{2}=158.01$, d.f. $=3$, $\mathrm{P}<0.001$; Figs. 1 and 2). Specifically, those in the acidified treatment were significantly smaller than in the control (Dunn $\mathrm{z}=-8.58, \mathrm{P}<0.001$ ), those in the warm treatment were significantly larger than in the control $(\mathrm{z}=3.15, \mathrm{P}<0.001)$, and those in the warm acidified treatment did not differ significantly from those in the control $(\mathrm{z}=1.05, \mathrm{P}=0.932)$. Temperature and $\mathrm{pH}$ treatments also influenced birefringence scores in larvae aged 40 hours (Kruskal-Wallis $\chi^{2}=137.05$, d.f. $=3, \mathrm{P}<0.001$; Figs. 1 and 2). Here, larvae from acidified treatments were not significantly less calcified than those in the control $(\mathrm{z}=-1.31, \mathrm{P}=0.566)$; however, those in the warm treatment were significantly more calcified than in the control $(\mathrm{z}=8.61, \mathrm{P}<0.001)$, as were those in the warm acidified treatment $(\mathrm{z}=6.59, \mathrm{P}<0.001)$. Furthermore, larvae from warm acidified treatments were significantly less calcified than those from the warm treatment $(\mathrm{z}=$ $-2.44, \mathrm{P}=0.044)$.

\section{Differential expression of proteins and protein identification}

Total proteins from oyster larvae from the four conditions (control, acidified, warm and warm acidified) were extracted and separated by 2-DE. After Coomassie blue staining, an average of 650 spots were detected on each gel (Fig. 3). In total 12 spots were found to be differentially expressed at our significance level of $\mathrm{P}<0.02$ (Fig. 3) in at least one condition. All of these 12 protein spots were excised from gels, trypsinized and identified by LCMS/MS (Table 1). Two spots that were both identified as severin (5 and 6) appeared to have 
similar molecular weights but different isoelectric points, suggesting post-translational modification of this protein, such as phosphorylation. Two proteins (spots 7 and 12) were assigned $C$. gigas UniProt IDs corresponding to uncharacterised proteins. A protein blast of K1QWT8_CRAGI yielded G9MBW9_PINMA (Shell matrix protein in Pinctada maxima) as the nearest characterised protein $(\mathrm{e}-\mathrm{value}=16 \mathrm{e}-9 ;$ score $=161 ;$ identity $=32.0 \%)$, while a protein blast of K1QVF8_CRAGI returned H9LJ92_CRAAR (USP-like protein isoform 2 in Crassostrea ariakensis) as the nearest characterised protein (e-value $=3.0 \mathrm{e}-18 ;$ score $=194$; identity $=58.0 \%)$. The direction and fold change in expression of all proteins are shown in Figure 4 and summarised in Table 2. Seven of the proteins associated with these spots responded to reduced $\mathrm{pH}$ (the metabolic enzyme ATP synthase; intra-cellular-matrix proteins severin spots 5 and 6 , and actin-2; extra-cellular matrix proteins matrilin-2 and shell matrix protein, and the glycolipoprotein vitellogenin-6), four responded to increased temperature (molecular chaperones GRP78 and PDI 2; severin spot 5; and the stress response protein USP-like protein isoform 2), and six responded to concurrent $\mathrm{pH}$ reduction and warming in the control vs warm acidified comparison (matrilin-2, ATP synthase, vitellogenin-6, USP-like protein isoform 2; the metabolic enzyme GAPDH, and the stress response protein SOD). Most proteins that responded to $\mathrm{pH}$ were less abundant when $\mathrm{pH}$ was reduced (five of seven: matrilin-2, ATP synthase, severin spots 5 and 6 and actin-2), while most proteins that responded to temperature were more abundant when temperature increased (three of four: GRP78, PDI 2, severin spot 5). Four of the six spots which responded to concurrent pH reduction and warming were less abundant (matrilin-2, ATP synthase, GAPDH, USP-like protein isoform 1). Furthermore, as Fig. 4 demonstrates, although the combined effects of reduced $\mathrm{pH}$ and warming were in some cases additive and synergistic (e.g. matrilin-2 and SOD), the combination of the two environmental variables also resulted in unexpected nonadditive effects on metabolism, such as the larger fold changes in ATP synthase and 
vitellogenin that occurred when both $\mathrm{pH}$ and temperature were considered together, despite the variables seeming to act in the opposite directions when considered singly.

\section{Discussion}

Phenotypic effects of $\mathrm{pH}$ and temperature treatments

Larvae reared in the acidified treatment were significantly smaller in size than those in any of the other treatments, suggesting that a reduction in $\mathrm{pH}$ may lead either to reduced growth or retarded development [49]. Although larvae reared in the warm treatment were larger than control animals, those reared in the warm acidified treatment did not differ significantly in size from control animals, suggesting that concomitant warming may mitigate the negative effect of acidification on size [26]. In contrast, the acidified treatment did not result in a significant reduction in birefringence versus the control. However, birefringence scores were higher in the warm and warm acidified treatment than in the control, and larvae from the warm acidified treatment had lower birefringence scores than those from the warm treatment. This suggests that at higher temperatures, effects of acidification on calcification in C. gigas larvae may become more visible, and that size and calcification are influenced by temperature and $\mathrm{pH}$ in different ways.

\section{Proteomic response to $\mathrm{pH}$}

One of the largest fold changes to occur in the $C$. gigas larval proteome was the reduction in ATP synthase subunit $\mathrm{b}$ in acidification comparisons at both temperatures; a 2-fold reduction at $20^{\circ} \mathrm{C}$, and a 5 -fold reduction at $22^{\circ} \mathrm{C}$. ATP synthase is a protein complex located in the mitochondrial inner membrane that plays a fundamental role in ATP synthesis in all living 
organisms [50], and is constitutively expressed at high levels in adult $C$. gigas [51]. ATP synthase gene expression was reduced in two studies of sea urchin larvae exposed to weak acidification ( $\mathrm{pH}$ reduction of $0.05-0.15$ units) [52,53], and protein abundance was also reduced when larvae of the polychaete Hydroides elegans were exposed to a $\mathrm{pH}$ reduction of 0.4 units [54]. A reduction in the abundance of ATP synthase at low $\mathrm{pH}$ points to a reduced ability to produce energy via oxidative metabolism. This may result from changes to the energy budget in response to reduced $\mathrm{pH}$, and may also arise due to retarded development. ATP synthase increases in abundance during larval development of $C$. gigas [55], so the reduction we observed could be the result of a developmental delay. The presence of 3.5-fold higher levels of vitellogenin following $\mathrm{pH}$ reduction at $22^{\circ} \mathrm{C}$ may corroborate this fact: vitellogenins are glycolipoproteins that act as yolk proteins for developing embryos in oviparous species [56]. Transcript [57] and protein [58] abundance of vitellogenin has been shown to decline during larval development of marine invertebrates as these maternally provisioned resources are consumed for nourishment. Therefore increased levels of vitellogenin in the warm acidified treatment could suggest that these resources are being consumed at a slower rate, which together with reduced ATP synthase abundance may point towards developmental retardation. Reduced development or growth as a result of reduced ATP synthase abundance could also help to explain the smaller size of animals in the acidified treatment compared to animals in the control.

Aside from vitellogenin, the only protein to show a positive change when $\mathrm{pH}$ was reduced was an initially uncharacterised protein, which showed increased accumulation in the warm acidified treatment versus the warm treatment. Blasting the amino acid sequence against the UniProt database found the nearest homolog to be a shell matrix protein from the Silverlipped pearl oyster Pinctada maxima (e-value $=16$ e-9) This protein is itself a homolog of the better characterised aspein, as identified in the Akoya pearl oyster, Pinctada fucata [59]. 
Expression of the aspein gene occurs in the prismatic layer of the shell matrix in Pinctada species $[59,60]$, suggesting a role in biomineralisation. Our identification of increased shell matrix protein abundance in warm acidified versus warm conditions suggest that its accumulation may be a compensatory response to multiple environmental drivers, although in contrast to our results, Liu et al [61] found that gene expression of aspein was downregulated in adult $P$. fucata exposed to acidification and warming, and it is unclear if such differences arise due to species, life stage or expression/translation differences. Conversely, a different extra-cellular matrix protein, matrilin-2, accumulated less in the acidified compared to the control treatments. Matrilins are involved in vertebrate biomineralisation processes [62] facilitating the deposition of collagen [63], and may serve a similar function in molluscs, as similar proteins have been found have a role in collagen binding-matrix protein in the byssus (attachment structure) of M. galloprovincialis [64]. However, matrilins have also been associated with Mytilus immune responses [65] and neural stimulation in Aplysia [66], making it difficult to speculate on its role here in response to warming and acidification.

Comparing animals from the warm acidified treatment with animals from the warm treatment revealed reduced abundance of the cytoskeletal protein actin and the actin-binding protein severin (spot 5) as $\mathrm{pH}$ declined: an alternative isoform of severin (spot 6) was also less abundant in acidified versus control animals. Actins are highly abundant proteins within eukaryotic cells, while severins are part of the gelsolin family of capping proteins which regulate actin length [67]. Changes in structural protein abundance could be a sign of cytoskeletal remodeling, as structural proteins are key regulators of many cellular processes relating to cell division and shape [68], However, given their ubiquity of these proteins in eukaryotic cells, reduced accumulation of actin and severin at lower pHs may simply reflect fewer cells in these individuals, which again may be the result of a developmental delay. Other studies on marine invertebrates have shown reduced abundance of cytoskeletal proteins 
in response to OA. Beta-tubulin was down-regulated in C. gigas larvae reared under acidification [69], and both actin and tubulin were down-regulated in larvae of the tubeworm Hydroides elegans reared at $\mathrm{pH} 7.6$ versus $\mathrm{pH} 8.1$ [54].

\section{Proteomic response to temperature}

Rising temperatures resulted in the increased abundance of three proteins: two molecular chaperones (PDI 2 and GRP78) and severin (spot 5), and the reduced abundance of a single stress-protein (USP-like protein isoform 2). PDI (Protein disulphide isomerase) 2 responded positively to warming at $\mathrm{pH} 7.9$, while GRP78, belonging to the heat-shock70 family of proteins, responded positively to warming at $\mathrm{pH}$ 8.1. The formation of disulphide bonds, as facilitated by PDIs, is a key step in protein folding for many extracellular proteins [70], ensuring their stability under variable environmental conditions, and PDI has been demonstrated to be a marker of quality in C. gigas oocytes [37]. PDIs may sequester reactive oxygen species (ROS) [71], and both PDIs and GRP78 help to prevent oxidative stress damage [72], often acting in concert with one another [73]. The expression of GRP78 following long-term thermal stress has been previously demonstrated in adult Mytilus species [74]; our results suggest that increased production of molecular chaperones may be a normal acclimatory response by $C$. gigas larvae even when temperature differences are only slight. The only protein to show decreased abundance in response to warming was universal stress protein (USP) like protein isoform 2, which accumulated less in larvae from the warm acidified treatment compared to the acidified treatment. USPs are a diverse family of proteins that, although initially characterised in bacteria, are also present in plants, fungi and metazoans. Although their functions are often linked to physiological stress responses [75], USP-like proteins have been suggested to facilitate calcification in the coral Acropora 
millepora [76], and to regulate growth in the bacterium Mycobacterium tuberculosis via an ATP binding function [77]. A pH sensitive isoform of USP was identified in larvae of the closely-related Hong Kong oyster Crassostrea hongkongensis [78] and further research into expression and function of this protein family may improve our understanding of its role in larval responses to $\mathrm{pH}$ and temperature change.

The interaction of $\mathrm{pH}$ and temperature on the proteome

Sea surface temperature increases and ocean acidification are two inextricably linked changes associated with climate change. The choice of the assayed temperature $\left(+2^{\circ} \mathrm{C}\right)$ and $\mathrm{pH}(-0.2$ $\mathrm{pH}$ units, or $p \mathrm{CO}_{2}$ of $\left.650 \mu \mathrm{atm}\right)$ in this study correspond to the predicted end-of-the-century conditions attained under the intermediate-high $\mathrm{CO}_{2}$ emissions scenario RCP6.0 [IPCC RCP6.0; 1]. Therefore, as well as identifying proteins that respond to changes in $\mathrm{pH}$ and temperature as single environmental variables, it is critical to consider how multiple concurrent changes to the environment will alter protein abundance. In larvae reared in the warm acidified treatment, six spots were identified as differentially abundant when compared to the control. Four of these were differentially abundant in either acidified (ATP synthase, matrilin-2, vitellogenin-6) or warm (USP-like protein isoform 2) treatments. Two proteins, however, were identified only when the comparison between control and warm acidified was considered: the metabolic enzyme GAPDH showed reduced abundance, while the stressresponse enzyme superoxide dismutase (SOD) displayed increased abundance. Both the increase in SOD and decrease in GAPDH could indicate a response to oxidative stress under warming and acidification. SOD is a key stress response of bivalves to warming [79] that is highly abundant in adult $C$. gigas [51] and actively expressed during metabolically active periods of development in marine invertebrates [80]. More abundant SOD in the warm 
acidified versus the control treatment suggests that the effect of these two environmental changes together results in more oxidative stress than when they are considered individually, possibly as a result of a metabolic shift. Such a shift may arise due to GAPDH. This protein alters carbohydrate flux, with reduced expression switching metabolism from glycolysis to pentose phosphate synthesis $[33,81]$, allowing the maintenance of sufficient reducing equivalents to counteract oxidative stress, as has been shown in cold-stressed fish [82]. Furthermore, GAPDH was recently identified to be down-regulated in a 2-DE based study on thermal acclimation in the scallop Pecten maximus [83]. As well as its established role in the glycolytic pathway, GAPDH also appears to be involved in a diverse range of cellular processes, including as a transcription factor interacting with RNA polymerase II [84], a signal protein via the mTOR pathway [85] and binding to various nucleic acids [86], suggesting that it is a central node in a network of thermo-regulated genes and proteins and may play a pivotal role in thermal acclimation [83].

\section{Proteomic mechanisms underlying phenotypic changes}

Proteomic responses to acidification and warming can provide insight into the observed differences in phenotypic traits such as size and biomineralisation. One compelling result is the general decline in protein abundance when comparing acidified or warm acidified treatments with the control and/or warm treatments, which may be an underlying factor of reduced size in the acidified treatment, and reduced calcification in the warm acidified versus the warm treatment. A previous study of acidification on $C$. gigas larvae found a similar decline in protein abundance in lower $\mathrm{pH}$ treatments [69], which may arise because marine invertebrates are often unable to effectively regulate the $\mathrm{pH}$ of their extracellular spaces $[87,88]$, leading to reduced protein biosynthesis in acidified conditions [89] and 
developmental delay. Development may also be slowed by lower levels of ATP synthase reducing energy availability, and increased vitellogenin could indicate less consumption of maternal resources and therefore slower development. Acidification-induced delays have previously been observed to result in reduced size at a given age [90,91], in line with our own observations of reduced size. Conversely, increased temperature typically results in faster development and growth for ectotherms [92]. Increased protein metabolism is an underlying factor in faster rates of growth and development [93], and accumulation of protein chaperones such as GRP78 and PDI 2 may ensure the correct folding of proteins [33] as protein turnover increases, thus permitting larvae in the warm treatment to reach a larger size and to calcify to a greater extent than control animals.

The opposite actions of acidification and warming on rate of development may explain why larvae exposed to both simultaneously do not differ significantly in size from those in the control group, and supports the idea that increased temperature appears to mitigate some negative effects of acidification on larval development [26,27]. Certain changes to the proteome could underlie this compensatory effect: reduced ATP synthase and GAPDH are evidence of a shift away from catabolism, towards anabolism and biomass accumulation, or growth [94]. However, this metabolic strategy is unlikely to be sustainable in the long term as energy resources are likely to be depleted. Indeed, a recent study by Ko et al found that even though temperature compensated for the developmental delay induced by acidification, physiological quality was compromised [28].

\section{Conclusion}

Our results add to growing body of work investigating the proteomic and phenotypic responses of marine invertebrate larvae in response to multiple climatic drivers $[28,54]$. In 
agreement with other studies, warming was able to mitigate some of the phenotypic negative effects of acidification on larval development [26-28]. However, our results also show that even if phenotypic differences are minor, protein accumulation is modified when considering the combination of reduced $\mathrm{pH}$ and increased temperature. Such differential accumulation produced additive responses, as was the case with SOD in which $\mathrm{pH}$ and temperature acted in the same direction individually as when combined, but also non-additive responses, as was the case for ATP synthase where $\mathrm{pH}$ and temperature acted in opposite directions but together resulted in a magnified response to $\mathrm{pH}$. These changes to the proteome underlie developmental plasticity and, to a certain extent, permit larval acclimation to changing environments. However, acclimation may not be sustainable over long periods and could carry later-life costs [95]. The identification of differential abundance of key proteins such as ATP synthase, GAPDH and SOD during early development is an important step in understanding molecular mechanisms underpinning developmental plasticity of C. gigas larvae in environments with reduced $\mathrm{pH}$ and increased temperature. However, further proteomic studies are required to validate these results and investigate acclimatory protein responses over longer developmental periods and adaptive ones across generations. Moreover, information about protein abundance must be integrated with both preceding patterns of gene expression and subsequent measures of physiological quality such as lipid metabolism to better understand the mechanisms that might permit marine invertebrate larvae to cope with future climate change.

\section{Acknowledgements}

The authors thank Dominique Ratiskol, Isabelle Quéau and Bruno Petton of Ifremer, involved in oyster conditioning at the Argenton experimental hatchery; and Martin Protat for help during microscopy. We thank Mélanie Lagarrigue, Emmanuelle Com and Charles Pineau 
from the Proteomics Core Facility Protim, Inserm U1085, Rennes, France. We also thank PRIDE and ProteomeXchange for the dissemination of our data, and two anonymous reviewers for their comments, which improved an earlier version of this manuscript. This work was supported by a grant from the Regional Council of Brittany, from the European Funds (ERDF) and supported by the "Laboratoire d'Excellence" LabexMER (ANR-10LABX-19) and co-funded by a grant from the French government under the program "Investissements d'Avenir".

\section{References}

[1] IPCC. Climate Change 2013: The Physical Science Basis. Cambridge, UK: Cambridge University Press; 2013.

[2] Hansen J, Sato M, Ruedy R, Lo K, Lea DW, Medina-Elizade M. Global temperature change. Proc Natl Acad Sci U S A 2006;103:14288-93. doi:10.1073/pnas.0606291103.

[3] Caldeira K, Wickett ME. Anthropogenic carbon and ocean pH. Nature 2003;425:365.

[4] Caldeira K, Wickett ME. Ocean model predictions of chemistry changes from carbon dioxide emissions to the atmosphere and ocean. J Geophys Res 2005;110:1-12. doi:10.1029/2004JC002671.

[5] Sabine CL, Feely RA, Gruber N, Key RM, Lee K, Bullister JL, et al. The oceanic sink for anthropogenic $\mathrm{CO}_{2}$. Science 2004;305:367-71. doi:10.1126/science.1097403.

[6] Feely RA, Sabine CL, Lee K, Berelson W, Kleypas JA, Fabry VJ, et al. Impact of anthropogenic $\mathrm{CO}_{2}$ on the $\mathrm{CaCO}_{3}$ system in the oceans. Science 2004;305:362-6. doi:10.1126/science.1097329.

[7] Hofmann GE, Todgham AE. Living in the now: physiological mechanisms to tolerate a rapidly changing environment. Annu Rev Physiol 2010;72:127-45. doi:10.1146/annurev-physiol-021909-135900.

[8] Fabry VJ, Seibel B, Feely RA, Orr JC. Impacts of ocean acidification on marine fauna 
and ecosystem processes. ICES J Mar Sci 2008;65:414-32.

[9] Harvey BP, Gwynn-Jones D, Moore PJ. Meta-analysis reveals complex marine biological responses to the interactive effects of ocean acidification and warming. Ecol Evol 2013;3:1016-30. doi:10.1002/ece3.516.

[10] Kroeker KJ, Kordas RL, Crim R, Hendriks IE, Ramajo L, Singh GS, et al. Impacts of ocean acidification on marine organisms: Quantifying sensitivities and interaction with warming. Glob Chang Biol 2013;19:1884-96. doi:10.1111/gcb.12179.

[11] Byrne M, Ho M, Wong E, Soars NA, Selvakumaraswamy P, Sheppard Brennand H, et al. Unshelled abalone and corrupted urchins: development of marine calcifiers in a changing ocean. Proc R Soc B Biol Sci 2011;278:2376-83. doi:10.1098/rspb.2010.2404.

[12] Waldbusser GG, Hales B, Langdon CJ, Haley BA, Schrader P, Brunner EL, et al. Saturation-state sensitivity of marine bivalve larvae to ocean acidification. Nat Clim Chang 2015;5:273-80. doi:10.1038/NCLIMATE2479.

[13] Byrne M. Global change ecotoxicology: Identification of early life history bottlenecks in marine invertebrates, variable species responses and variable experimental approaches. Mar Environ Res 2012;76:3-15. doi:10.1016/j.marenvres.2011.10.004.

[14] Havenhand JN, Buttler F, Thorndyke MC, Williamson JE. Near-future levels of ocean acidification reduce fertilization success in a sea urchin. Curr Biol 2008;R651:651-2. doi:10.1029/2004JC002671.6.Styan.

[15] Talmage SC, Gobler CJ. Effects of past, present, and future ocean carbon dioxide concentrations on the growth and survival of larval shellfish. Proc Natl Acad Sci U S A 2010;107:17246-51. doi:10.1073/pnas.0913804107.

[16] Barros P, Sobral P, Range P, Chícharo L, Matias D. Effects of sea-water acidification on fertilization and larval development of the oyster Crassostrea gigas. J Exp Mar Bio Ecol 2013;440:200-6. doi:10.1016/j.jembe.2012.12.014.

[17] Kurihara $\mathrm{H}$, Kato S, Ishimatsu A. Effects of increased seawater $\mathrm{pCO}_{2}$ on early development of the oyster Crassostrea gigas. Aquat Biol 2007;1:91-8. doi:10.3354/ab00009.

[18] Kurihara $\mathrm{H}$, Asai T, Kato S, Ishimatsu A. Effects of elevated $\mathrm{pCO}_{2}$ on early development in the mussel Mytilus galloprovincialis. Aquat Biol 2008;4:225-33. doi:10.3354/ab00109. 
[19] Parker LM, Ross PM, O'Connor WA. The effect of ocean acidification and temperature on the fertilization and embryonic development of the Sydney rock oyster Saccostrea glomerata (Gould 1850). Glob Chang Biol 2009;15:2123-36. doi:10.1111/j.1365-2486.2009.01895.x.

[20] Parker LM, Ross PM, O'Connor WA. Comparing the effect of elevated $\mathrm{pCO}_{2}$ and temperature on the fertilization and early development of two species of oysters. Mar Biol 2010;157:2435-52. doi:10.1007/s00227-010-1508-3.

[21] Kurihara $\mathrm{H}$. Effects of $\mathrm{CO}_{2}$-driven ocean acidification on the early developmental stages of invertebrates. Mar Ecol Prog Ser 2008;373:275-84. doi:10.3354/meps07802.

[22] Barry JP, Tyrell T, Hansson L, Plattner G-K, Gattuso J-P. Atmospheric $\mathrm{CO}_{2}$ targets for ocean acidification perturbation experiments. In: Riebesell U, Fabry VJ, Hansson L, Gattuso J-P, editors. Guid. to Best Pract. Ocean Acidif. Res., Brussels, Belgium: European Comission; 2010, p. 53-66.

[23] Harley CDG, Randall Hughes A, Hultgren KM, Miner BG, Sorte CJB, Thornber CS, et al. The impacts of climate change in coastal marine systems. Ecol Lett 2006;9:22841. doi:10.1111/j.1461-0248.2005.00871.x.

[24] Kelly MW, Padilla-Gamiño JL, Hofmann GE. Natural variation and the capacity to adapt to ocean acidification in the keystone sea urchin Strongylocentrotus purpuratus. Glob Chang Biol 2013;19:2536-46. doi:10.1111/gcb.12251.

[25] Timmins-Schiffman EB, O’Donnell MJ, Friedman CS, Roberts SB. Elevated $\mathrm{pCO}_{2}$ causes developmental delay in early larval Pacific oysters, Crassostrea gigas. Mar Biol 2013;160:1973-82. doi:10.1007/s00227-012-2055-x.

[26] Sheppard Brennand H, Soars NA, Dworjanyn SA, Davis AR, Byrne M. Impact of ocean warming and ocean acidification on larval development and calcification in the sea urchin Tripneustes gratilla. PLoS One 2010;5:e11372. doi:10.1371/journal.pone.0011372.

[27] Byrne M, Foo S, Soars NA, Wolfe KDL, Nguyen HD, Hardy N, et al. Ocean warming will mitigate the effects of acidification on calcifying sea urchin larvae (Heliocidaris tuberculata) from the Australian global warming hot spot. J Exp Mar Bio Ecol 2013;448:250-7. doi:10.1016/j.jembe.2013.07.016.

[28] Ko WKG, Dineshram R, Campanati C, Vera CBS, Havenhand JN, Thiyagarajan V. Interactive Effects of Ocean Acidification, Elevated Temperature and Reduced Salinity on Early-Life Stages of the Pacific Oyster. Environ Sci Technol 2014;48:10079-88. doi:10.1021/es501611u. 
[29] Benton TG, Plaistow SJ, Coulson TN. Complex population dynamics and complex causation: devils, details and demography. Proc R Soc B Biol Sci 2006;273:1173-81. doi:10.1098/rspb.2006.3495.

[30] Beldade P, Mateus ARA, Keller RA. Evolution and molecular mechanisms of adaptive developmental plasticity. Mol Ecol 2011;20:1347-63. doi:10.1111/j.1365294X.2011.05016.x.

[31] West-Eberhard MJ. Developmental plasticity and evolution. New York: Oxford University Press; 2003.

[32] Pespeni MH, Sanford E, Gaylord B, Hill TM, Hosfelt JD, Jaris HK, et al. Evolutionary change during experimental ocean acidification. Proc Natl Acad Sci U S A 2013:1-6. doi:10.1073/pnas.1220673110.

[33] Tomanek L. Proteomics to study adaptations in marine organisms to environmental stress. J Proteomics 2014;105:92-106. doi:10.1016/j.jprot.2014.04.009.

[34] Scyphers SB, Powers SP, Heck KL, Byron D. Oyster reefs as natural breakwaters mitigate shoreline loss and facilitate fisheries. PLoS One 2011;6:e22396. doi:10.1371/journal.pone.0022396.

[35] Epelboin Y, Quéré C, Pernet F, Pichereau V, Corporeau C. Energy and Antioxidant Responses of Pacific Oyster Exposed to Trace Levels of Pesticides. Chem Res Toxicol 2015;28:1831-41. doi:10.1021/acs.chemrestox.5b00269.

[36] Corporeau C, Tamayo D, Pernet F, Quéré C, Madec S. Proteomic signatures of the oyster metabolic response to herpesvirus OsHV $-1 \mu$ Var infection. J Proteomics 2014;109:176-87. doi:10.1016/j.jprot.2014.06.030.

[37] Corporeau C, Vanderplancke G, Boulais M, Suquet M, Quéré C, Boudry P, et al. Proteomic identification of quality factors for oocytes in the Pacific oyster Crassostrea gigas. J Proteomics 2012;75:5554-63. doi:10.1016/j.jprot.2012.07.040.

[38] Song YP, Suquet M, Quéau I, Lebrun L. Setting of a procedure for experimental fertilisation of Pacific oyster (Crassostrea gigas) oocytes. Aquaculture 2009;287:3114. doi:10.1016/j.aquaculture.2008.10.018.

[39] Pierrot D, Lewis E, Wallace DWR. MS Excel Program Developed for $\mathrm{CO}_{2}$ System Calculations. ORNL/CDIAC-105a. 2006. doi:10.3334/CDIAC/otg.CO2SYS_XLS_CDIAC105a. 
[40] Cai W-J, Wang Y. The chemistry, fluxes, and sources of carbon dioxide in the estuarine waters of the Satilla and Altamaha Rivers, Georgia. Limnol Oceanogr 1998;43:657-68. doi:10.4319/lo.1998.43.4.0657.

[41] Guévélou E, Huvet A, Galindo-Sánchez CE, Milan M, Quillien V, Daniel J-Y, et al. Sex-specific regulation of AMP-activated protein kinase (AMPK) in the Pacific oyster Crassostrea gigas. Biol Reprod 2013;89:100. doi:10.1095/biolreprod.113.109728.

[42] Rasband WS. ImageJ, U.S. National Institute of Health, Bethesda, Maryland, USA, http://rsb.info.nih.gov/ij/, 1997-2009 1997.

[43] Noisette F, Comtet T, Legrand E, Bordeyne F, Davoult D, Martin S. Does encapsulation protect embryos from the effects of ocean acidification? The example of Crepidula fornicata. PLoS One 2014;9:e93021. doi:10.1371/journal.pone.0093021.

[44] Dinno A. dunn.test: Dunn's Test of Multiple Comparisons Using Rank Sums 2015.

[45] R Development Core Team. R: A language and environment for statistical computing 2014.

[46] Galland C, Dupuy C, Capitaine C, Auffret M, Quiniou L, Laroche J, et al. Comparisons of liver proteomes in the European flounder Platichthys flesus from three contrasted estuaries. J Sea Res 2013;75:135-41. doi:10.1016/j.seares.2012.05.009.

[47] Artigaud S, Lavaud R, Thébault J, Jean F, Strand $\varnothing$, Strohmeier T, et al. Proteomicbased comparison between populations of the great scallop, Pecten maximus. $\mathbf{J}$ Proteomics 2014;105:164-73. doi:10.1016/j.jprot.2014.03.026.

[48] Tomanek L, Zuzow MJ, Ivanina A V., Beniash E, Sokolova IM. Proteomic response to elevated $\mathrm{PCO}_{2}$ level in eastern oysters, Crassostrea virginica: evidence for oxidative stress. J Exp Biol 2011;214:1836-44. doi:10.1242/jeb.055475.

[49] Stumpp M, Wren J, Melzner F, Thorndyke MC, Dupont S. $\mathrm{CO}_{2}$ induced seawater acidification impacts sea urchin larval development I: Elevated metabolic rates decrease scope for growth and induce developmental delay. Comp Biochem Physiol Part A Mol Integr Physiol 2011;160:331-40. doi:10.1016/j.cbpa.2011.06.022.

[50] Yoshida M, Muneyuki E, Hisabori T. ATP synthase - a marvellous rotary engine of the cell. Nat Rev Mol Cell Biol 2001;2:669-77. doi:10.1038/35089509.

[51] Timmins-Schiffman EB, Nunn BL, Goodlett DR, Roberts SB. Shotgun proteomics as a viable approach for biological discovery in the Pacific oyster. Conserv Physiol 
2013;1:cot009. doi:10.1093/conphys/cot009.

[52] Todgham AE, Hofmann GE. Transcriptomic response of sea urchin larvae Strongylocentrotus purpuratus to $\mathrm{CO}_{2}$-driven seawater acidification. J Exp Biol 2009;212:2579-94. doi:10.1242/jeb.032540.

[53] O’Donnell MJ, Todgham AE, Sewell MA, Hammond LM, Ruggiero K, Fangue NA, et al. Ocean acidification alters skeletogenesis and gene expression in larval sea urchins. Mar Ecol Prog Ser 2010;398:157-71. doi:10.3354/meps08346.

[54] Mukherjee J, Wong KKW, Chandramouli KH, Qian P-Y, Leung PTY, Wu RSS, et al. Proteomic response of marine invertebrate larvae to ocean acidification and hypoxia during metamorphosis and calcification. J Exp Biol 2013;216:4580-9. doi:10.1242/jeb.094516.

[55] Huan P, Wang H, Dong B, Liu B. Identification of differentially expressed proteins involved in the early larval development of the Pacific oyster Crassostrea gigas. $\mathrm{J}$ Proteomics 2012;75:3855-65. doi:10.1016/j.jprot.2012.04.051.

[56] Wahli W, Dawid IB, Ryffel GU, Weber R. Vitellogenesis and the vitellogenin gene family. Science 1981;212:298-304.

[57] Li Y, Sun D, Qin Z, Zhang Z. Expression pattern of the vitellogenin gene in the zhikong scallop, Chlamys farreri, during ontogenesis. Mar Biol Res 2014;10:917-26. doi:10.1080/17451000.2013.863356.

[58] Nomura M, Nakajima A, Inaba K. Proteomic profiles of embryonic development in the ascidian Ciona intestinalis. Dev Biol 2009;325:468-81.

doi:10.1016/j.ydbio.2008.10.038.

[59] Takeuchi T, Endo K. Biphasic and dually coordinated expression of the genes encoding major shell matrix proteins in the pearl oyster Pinctada fucata. Mar Biotechnol 2006;8:52-61. doi:10.1007/s10126-005-5037-x.

[60] Joubert C, Piquemal D, Marie B, Manchon L, Pierrat F, Zanella-Cléon I, et al. Transcriptome and proteome analysis of Pinctada margaritifera calcifying mantle and shell: focus on biomineralization. BMC Genomics 2010;11:613. doi:10.1186/14712164-11-613.

[61] Liu W, Huang X, Lin J, He M. Seawater acidification and elevated temperature affect gene expression patterns of the pearl oyster Pinctada fucata. PLoS One 2012;7. doi:10.1371/journal.pone.0033679. 
[62] Klatt AR, Becker AKA, Neacsu CD, Paulsson M, Wagener R. The matrilins: Modulators of extracellular matrix assembly. Int J Biochem Cell Biol 2011;43:320-30. doi:10.1016/j.biocel.2010.12.010.

[63] Neacsu CD, Ko YP, Tagariello A, Røkenes Karlsen K, Neiss WF, Paulsson M, et al. Matrilin-1 is essential for zebrafish development by facilitating collagen II secretion. $\mathrm{J}$ Biol Chem 2014;289:1505-18. doi:10.1074/jbc.M113.529933.

[64] Suhre MH, Scheibel T. Structural diversity of a collagen-binding matrix protein from the byssus of blue mussels upon refolding. J Struct Biol 2014;186:75-85. doi:10.1016/j.jsb.2014.02.013.

[65] Ji C, Wu H, Wei L, Zhao J, Wang Q, Lu H. Responses of Mytilus galloprovincialis to bacterial challenges by metabolomics and proteomics. Fish Shellfish Immunol 2013;35:489-98. doi:10.1016/j.fsi.2013.05.009.

[66] Lee Y-S, Choi S-L, Kim T-H, Lee J-A, Kim HK, Kim H, et al. Transcriptome analysis and identification of regulators for long-term plasticity in Aplysia kurodai. Proc Natl Acad Sci U S A 2008;105:18602-7. doi:10.1073/pnas.0808893105.

[67] Andre E, Lottspeich F, Schleicher M, Noegel A. Severin, gelsolin, and villin share a homologous sequence in regions presumed to contain F-actin severing domains. J Biol Chem 1988;263:722-7.

[68] Hammond JW, Cai D, Verhey KJ. Tubulin modifications and their cellular functions. Curr Opin Cell Biol 2008;20:71-6. doi:10.1016/j.ceb.2007.11.010.

[69] Dineshram R, Wong KKW, Xiao S, Yu Z, Qian PY, Thiyagarajan V. Analysis of Pacific oyster larval proteome and its response to high- $\mathrm{CO}_{2}$. Mar Pollut Bull 2012;64:2160-7. doi:10.1016/j.marpolbul.2012.07.043.

[70] Sevier CS, Kaiser CA. Formation and transfer of disulphide bonds in living cells. Nat Rev Mol Cell Biol 2002;3:836-47. doi:10.1038/nrm954.

[71] McDonagh B, Sheehan D. Effect of oxidative stress on protein thiols in the blue mussel Mytilus edulis: Proteomic identification of target proteins. Proteomics 2007;7:3395-403. doi:10.1002/pmic.200700241.

[72] Liu H, Bowes RC, Van De Water B, Sillence C, Nagelkerke JF, Stevens JL. Endoplasmic reticulum chaperones GRP78 and calreticulin prevent oxidative stress, $\mathrm{Ca} 2+$ disturbances, and cell death in renal epithelial cells. J Biol Chem 1997;272:21751-9. doi:10.1074/jbc.272.35.21751. 
[73] Ellgaard L, Helenius A. Quality control in the endoplasmic reticulum. Nat Rev Mol Cell Biol 2003;4:181-91. doi:10.1038/nrm1052.

[74] Fields PA, Zuzow MJ, Tomanek L. Proteomic responses of blue mussel (Mytilus) congeners to temperature acclimation. J Exp Biol 2012;215:1106-16. doi:10.1242/jeb.062273.

[75] Kvint K, Nachin L, Diez A, Nyström T. The bacterial universal stress protein: Function and regulation. Curr Opin Microbiol 2003;6:140-5. doi:10.1016/S13695274(03)00025-0.

[76] Forêt S, Seneca F, De Jong D, Bieller A, Hemmrich G, Augustin R, et al. Phylogenomics reveals an anomalous distribution of USP genes in metazoans. Mol Biol Evol 2011;28:153-61. doi:10.1093/molbev/msq183.

[77] Drumm JE, Mi K, Bilder P, Sun M, Lim J, Bielefeldt-Ohmann H, et al. Mycobacterium tuberculosis universal stress protein Rv2623 regulates bacillary growth by ATP-binding: Requirement for establishing chronic persistent infection. PLoS Pathog 2009;5. doi:10.1371/journal.ppat.1000460.

[78] Dineshram R, Thiyagarajan V, Lane A, Ziniu Y, Xiao S, Leung PTY. Elevated $\mathrm{CO}_{2}$ alters larval proteome and its phosphorylation status in the commercial oyster, Crassostrea hongkongensis. Mar Biol 2013;160:2189-205. doi:10.1007/s00227-0132176-x.

[79] Tomanek L, Zuzow MJ. The proteomic response of the mussel congeners Mytilus galloprovincialis and $M$. trossulus to acute heat stress: implications for thermal tolerance limits and metabolic costs of thermal stress. J Exp Biol 2010;213:3559-74. doi:10.1242/jeb.041228.

[80] Brady P, Elizur A, Williams R, Cummins SF, Knibb W. Gene expression profiling of the cephalothorax and eyestalk in Penaeus monodon during ovarian maturation. Int $\mathbf{J}$ Biol Sci 2012;8:328-43. doi:10.7150/ijbs.3517.

[81] Ralser M, Wamelink MM, Kowald A, Gerisch B, Heeren G, Struys E A, et al. Dynamic rerouting of the carbohydrate flux is key to counteracting oxidative stress. $\mathrm{J}$ Biol 2007;6:10. doi:10.1186/jbiol61.

[82] Ibarz A, Martín-Pérez M, Blasco J, Bellido D, De Oliveira E, Fernández-Borràs J. Gilthead sea bream liver proteome altered at low temperatures by oxidative stress. Proteomics 2010;10:963-75. doi:10.1002/pmic.200900528.

[83] Artigaud S, Richard J, Thorne MAS, Lavaud R, Flye-Sainte-Marie J, Jean F, et al. 
Diciphering the molecular adaptation of the king scallop (Pecten maximus) to heat stress using transcriptomics and proteomics. BMC Genomics n.d.

[84] Mitsuzawa H, Kimura M, Kanda E, Ishihama A. Glyceraldehyde-3-phosphate dehydrogenase and actin associate with RNA polymerase II and interact with its Rpb7 subunit. FEBS Lett 2005;579:48-52. doi:10.1016/j.febslet.2004.11.045.

[85] Lee MN, Ha SH, Kim J, Koh A, Lee CS, Kim JH, et al. Glycolytic flux signals to mTOR through glyceraldehyde-3-phosphate dehydrogenase-mediated regulation of Rheb. Mol Cell Biol 2009;29:3991-4001. doi:10.1128/MCB.00165-09.

[86] Nicholls C, Li H, Liu JP. GAPDH: A common enzyme with uncommon functions. Clin Exp Pharmacol Physiol 2012;39:674-9. doi:10.1111/j.1440-1681.2011.05599.x.

[87] Stumpp M, Hu MY, Melzner F, Gutowska MA, Dorey N, Himmerkus N, et al. Acidified seawater impacts sea urchin larvae $\mathrm{pH}$ regulatory systems relevant for calcification. Proc Natl Acad Sci 2012;109:18192-7. doi:10.1073/pnas.1209174109.

[88] Waldbusser GG, Brunner EL, Haley BA, Hales B, Langdon CJ, Prahl FG. A developmental and energetic basis linking larval oyster shell formation to acidification sensitivity. Geophys Res Lett 2013;40:1-6. doi:10.1002/grl.50449.

[89] Langenbuch M, Pörtner H-O. Energy budget of hepatocytes from Antarctic fish (Pachycara brachycephalum and Lepidonotothen kempi) as a function of ambient $\mathrm{CO}_{2}$ : pH-dependent limitations of cellular protein biosynthesis? J Exp Biol 2003;206:3895903. doi:10.1242/jeb.00620.

[90] Martin S, Richier S, Pedrotti M-L, Dupont S, Castejon C, Gerakis Y, et al. Early development and molecular plasticity in the Mediterranean sea urchin Paracentrotus lividus exposed to $\mathrm{CO}_{2}$-driven acidification. J Exp Biol 2011;214:1357-68. doi:10.1242/jeb.051169.

[91] Stumpp M, Dupont S, Thorndyke MC, Melzner F. $\mathrm{CO}_{2}$ induced seawater acidification impacts sea urchin larval development II: Gene expression patterns in pluteus larvae. Comp Biochem Physiol - A Mol Integr Physiol 2011;160:320-30.

doi:10.1016/j.cbpa.2011.06.023.

[92] Atkinson D. Temperature and organism size-a biological law for ectotherms? Adv Ecol Res 1994;25:1-58.

[93] Fraser KPP, Rogers AD. Protein metabolism in marine animals: The underlying mechanism of growth. Adv Mar Biol 2007;52:267-362. doi:http://dx.doi.org/10.1016/S0065-2881(06)52003-6. 
[94] Brown J, Gillooly J, Allen A, Savage VM, West G. Toward a metabolic theory of ecology. Ecology 2004;85:1771-89.

[95] Thompson EL, O’Connor WA, Parker LM, Ross PM, Raftos DA. Differential proteomic responses of selectively bred and wild-type Sydney rock oyster populations exposed to elevated $\mathrm{CO}_{2}$. Mol Ecol 2015;24:1248-62. doi:10.1111/mec.13111.

\section{Table captions}

Table 1. Differentially accumulated protein spots in Crassostrea gigas larvae under reduced $\mathrm{pH}$, increased temperature, or a combination of both, as identified by LC-MS/MS.

Table 2. Larval proteins significantly differentially accumulated in response to acidification at both temperatures, warming at both $\mathrm{pHs,} \mathrm{and} \mathrm{the} \mathrm{interaction} \mathrm{of} \mathrm{acidification} \mathrm{and} \mathrm{warming.}$ Significantly different comparisons with a p-value of $<0.02$ are highlighted.

\section{Figure legends}

Figure 1. Demonstration of size and calcification differences in C. gigas D-larvae under polarized light. Larva A was reared at $20^{\circ} \mathrm{C} \mathrm{pH} 8.1\left(\right.$ size $=4140 \mu \mathrm{m}^{2}$, greyscale $\left.=98.4\right)$; B at $20^{\circ} \mathrm{C} \mathrm{pH} 7.9\left(\right.$ size $=3546 \mu \mathrm{m}^{2}$, greyscale $\left.=98.2\right) ; \mathrm{C}$ at $22^{\circ} \mathrm{C} \mathrm{pH} 8.1\left(\right.$ size $=4202 \mu \mathrm{m}^{2}$, greyscale $=110.2)$, and $\mathrm{D}$ at $22^{\circ} \mathrm{C} \mathrm{pH} 7.9\left(\right.$ size $=3937 \mu \mathrm{m}^{2}$, greyscale $\left.=106.2\right)$

Figure 2. Boxplots showing C. gigas larval size as measured by area in $\mu \mathrm{m}^{2}(\mathrm{~A})$ and birefringence, as measured by greyscale score (B) after 40 hours, in two pH (7.9 and 8.1 units) and two temperature $\left(20\right.$ and $\left.22{ }^{\circ} \mathrm{C}\right)$ treatments. Boxes encompass the interquartile range (IQR: $1^{\text {st }}$ to $3^{\text {rd }}$ quartile), dashed lines cover data within $1.5 \times \mathrm{IQR}$, and outliers are represented by circles. 
Figure 3. Representative annotated 2-DE gel images of larval proteome at $20^{\circ} \mathrm{C} / \mathrm{pH} 8.1$ (A) and $22^{\circ} \mathrm{C} / \mathrm{pH} 7.9$ (B). Protein spots displaying significant changes are arrowed. The name of identified proteins is shown in Table 1 along with details of the corresponding mass spectrometry data.

Figure 4. Normalised expression values for 12 differentially accumulated proteins in the $C$. gigas larval proteome under four conditions: control $\left(\mathrm{C}: \mathrm{pH} 8.1,20^{\circ} \mathrm{C}\right)$, acidified $(\mathrm{A}: \mathrm{pH} 7.9$, $20^{\circ} \mathrm{C}$ ), warm (W: $\mathrm{pH} 8.1,22^{\circ} \mathrm{C}$ ) and warm acidified (WA: $\left.\mathrm{pH} 7.9,22^{\circ} \mathrm{C}\right)$. Corresponding fold changes and $\mathrm{P}$ values are displayed in Table 2. 

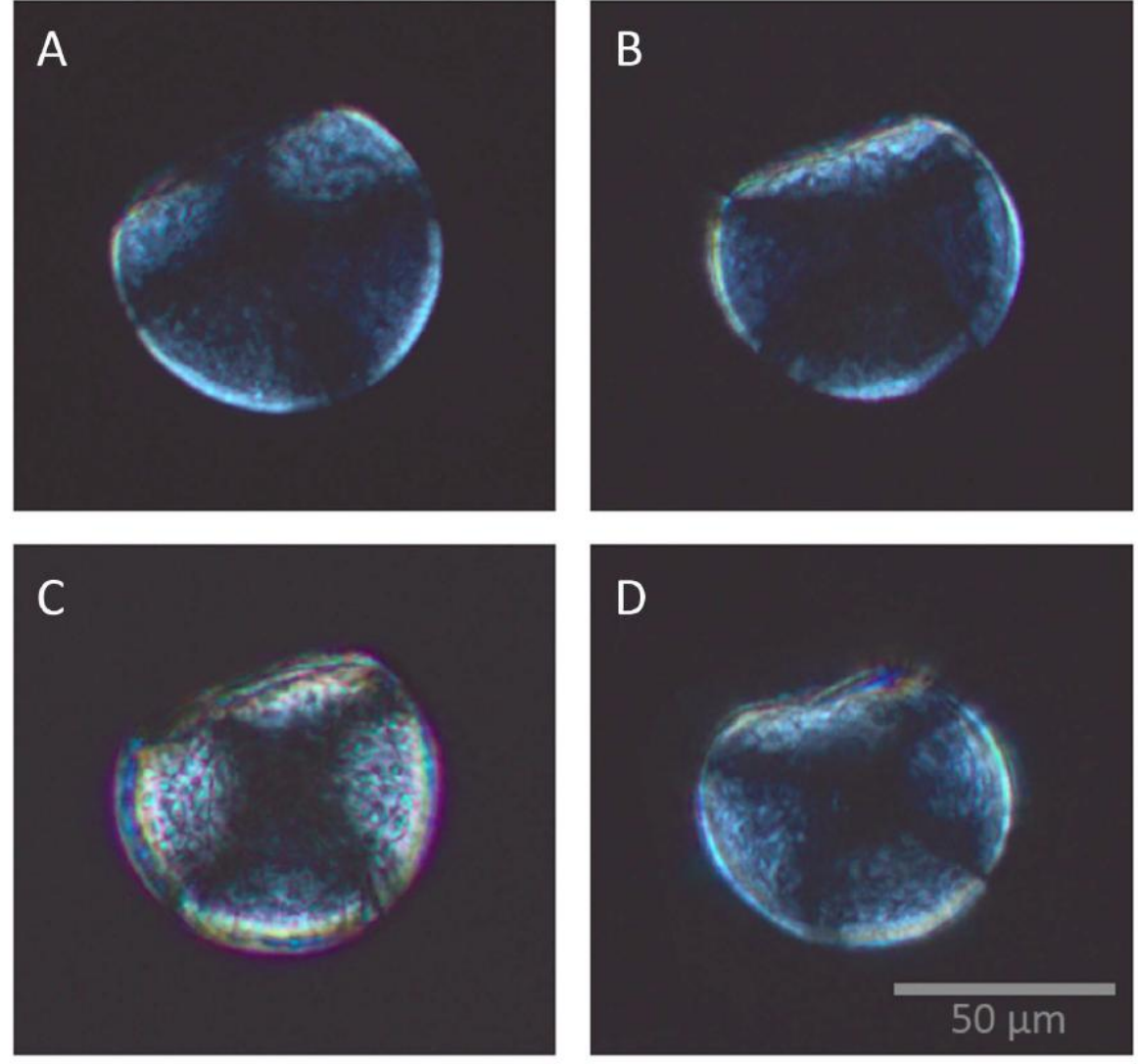

Fig. 1
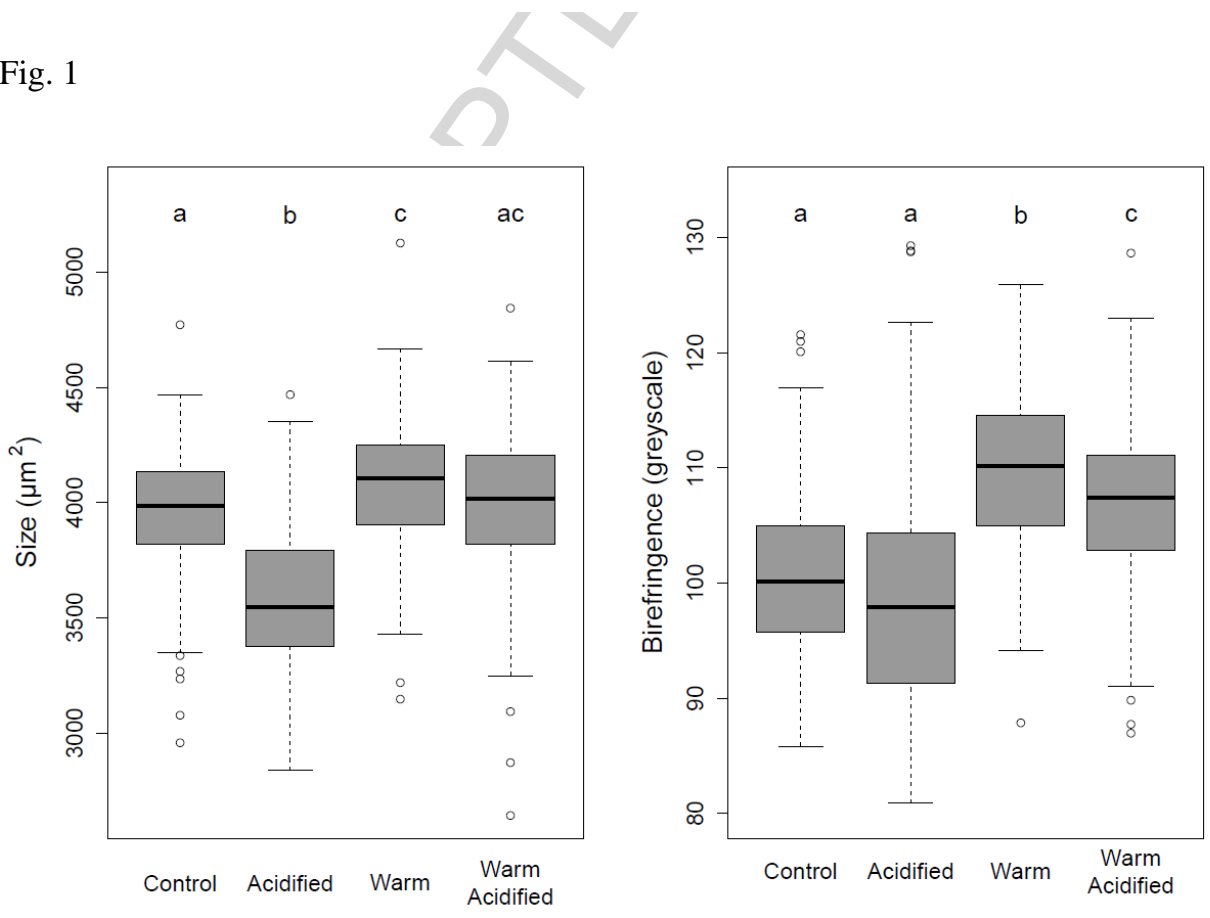

Fig. 2 


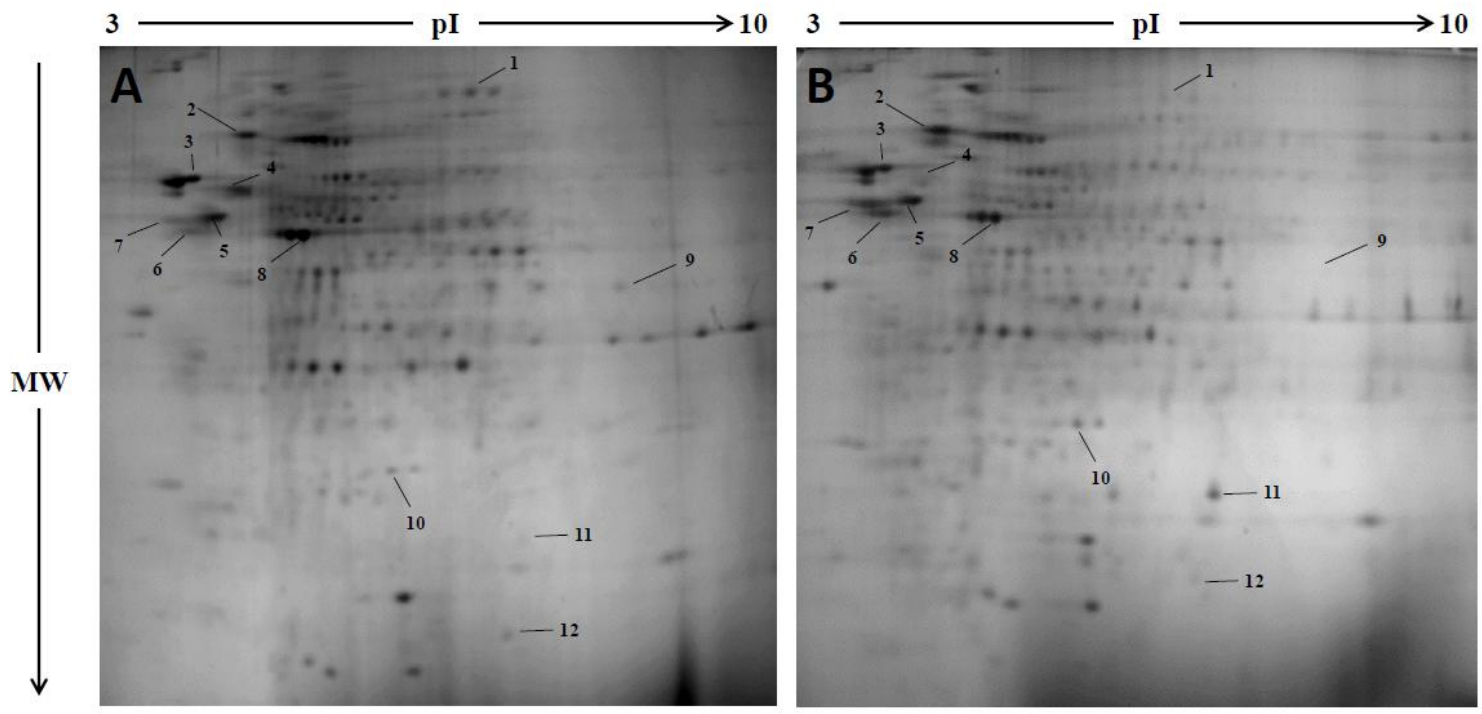

Fig. 3 

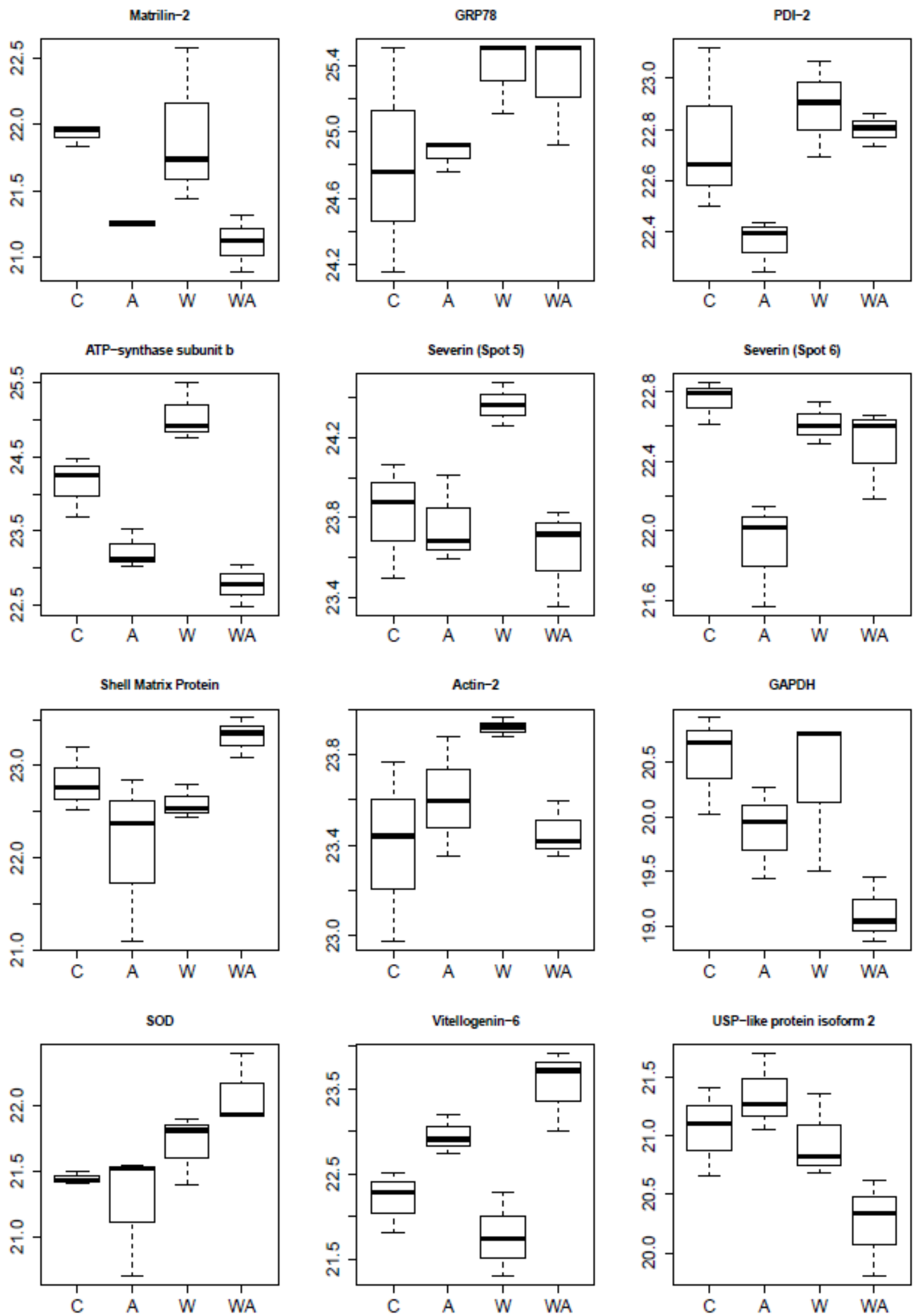

Fig. 4 
Table 1. Differentially accumulated protein spots in Crassostrea gigas larvae under reduced $\mathrm{pH}$, increased temperature, or a combination of both, as identified by LC-MS/MS.

\begin{tabular}{|c|c|c|c|c|c|c|c|c|}
\hline $\begin{array}{l}\text { Spot } \\
\text { numb } \\
\text { er }\end{array}$ & Protein annotation & $\begin{array}{l}\text { UniProt } \\
\text { ID }\end{array}$ & Organism & $\begin{array}{c}\text { MW } \\
(\mathrm{kDa}) / \mathrm{pI} \\
\text { theoretic } \\
\text { al }\end{array}$ & $\begin{array}{c}\text { MW } \\
(\mathrm{kDa}) \\
/ \mathrm{pI} \\
\text { Observe } \\
\mathrm{d}\end{array}$ & $\begin{array}{c}\text { Scor } \\
\mathrm{e}\end{array}$ & $\begin{array}{l}\text { Seq. } \\
\text { covera } \\
\text { ge }(\%)\end{array}$ & $\begin{array}{l}\text { Uniqu } \\
\mathrm{e} \\
\text { peptid } \\
\mathrm{e} \\
\text { match } \\
\text { es }\end{array}$ \\
\hline 1 & Matrilin-2 & $\begin{array}{l}\text { K1QD } \\
\text { H1 }\end{array}$ & $\begin{array}{l}\text { Crassostrea } \\
\text { gigas }\end{array}$ & $\begin{array}{c}81.2 / \\
6.61\end{array}$ & $\begin{array}{c}86.0 / \\
7.46\end{array}$ & $\begin{array}{c}101 \\
2\end{array}$ & 26 & 17 \\
\hline 2 & $\begin{array}{l}78 \mathrm{kDa} \text { glucose- } \\
\text { regulated protein } \\
(\mathrm{GRP78})\end{array}$ & $\begin{array}{c}\text { K1QIR } \\
8\end{array}$ & C. gigas & $\begin{array}{c}73.0 / \\
5.14\end{array}$ & $\begin{array}{c}66.1 / \\
4.97\end{array}$ & $\begin{array}{c}491 \\
9\end{array}$ & 58 & 42 \\
\hline 3 & $\begin{array}{l}\text { Protein disulfide- } \\
\text { isomerase } 2 \text { (PDI 2) }\end{array}$ & $\begin{array}{c}\text { K1Q6X } \\
5\end{array}$ & C. gigas & $\begin{array}{l}55.5 / \\
4.72\end{array}$ & $\begin{array}{l}54.4 / \\
4.51\end{array}$ & $\begin{array}{c}370 \\
4\end{array}$ & 52 & 25 \\
\hline 4 & $\begin{array}{l}\text { ATP synthase subunit } \\
\text { b }\end{array}$ & $\begin{array}{l}\text { K1RW } \\
\text { W5 }\end{array}$ & C. gigas & $\begin{array}{c}44.9 / \\
5.06\end{array}$ & $\begin{array}{l}51.7 / \\
4.92\end{array}$ & $\begin{array}{c}170 \\
3\end{array}$ & 41 & 13 \\
\hline 5 & Severin & $\begin{array}{c}\text { K1PE5 } \\
7\end{array}$ & C. gigas & $\begin{array}{l}37.2 / \\
4.88\end{array}$ & $\begin{array}{c}46.9 / \\
4.76\end{array}$ & $\begin{array}{c}362 \\
7\end{array}$ & 71 & 22 \\
\hline 6 & Severin & $\begin{array}{c}\text { K1PE5 } \\
7\end{array}$ & C. gigas & $\begin{array}{l}37.2 / \\
4.88\end{array}$ & $\begin{array}{l}45.7 / \\
4.63\end{array}$ & $\begin{array}{c}578 \\
4\end{array}$ & 68 & 21 \\
\hline 7 & Shell matrix protein & $\begin{array}{l}\text { G9MB } \\
\text { W9 }\end{array}$ & Pinctada maxima & $\begin{array}{c}45.1 / \\
4.5\end{array}$ & $\begin{array}{l}46.0 / \\
4.45\end{array}$ & 821 & 15 & 5 \\
\hline 8 & Actin-2 & $\begin{array}{l}\text { K1QW } \\
\text { P8 }\end{array}$ & C. gigas & $\begin{array}{c}41.8 / \\
5.48\end{array}$ & $\begin{array}{c}43.7 / \\
5.51\end{array}$ & $\begin{array}{c}151 \\
24\end{array}$ & 85 & 26 \\
\hline 9 & $\begin{array}{l}\text { Glyceraldehyde-3- } \\
\text { phosphate } \\
\text { dehydrogenase } \\
\text { (GAPDH) }\end{array}$ & 0 & C. gigas & $\begin{array}{c}36.1 / \\
7.34\end{array}$ & $\begin{array}{c}36.6 / \\
9.81\end{array}$ & $\begin{array}{c}130 \\
4\end{array}$ & 52 & 13 \\
\hline 10 & $\begin{array}{l}\text { Superoxide dismutase } \\
\text { (SOD) }\end{array}$ & $\begin{array}{l}\text { K1QG } \\
\text { Q5 }\end{array}$ & C. gigas & $\begin{array}{l}25.1 / \\
7.06\end{array}$ & $\begin{array}{c}19.9 / \\
6.48\end{array}$ & 100 & 22 & 3 \\
\hline 11 & Vitellogenin-6 & $\begin{array}{l}\text { K1QN } \\
\text { A2 }\end{array}$ & C. gigas & $\begin{array}{c}273.1 / \\
8.97\end{array}$ & $\begin{array}{l}15.1 / \\
8.19\end{array}$ & 585 & 5 & 9 \\
\hline 12 & $\begin{array}{l}\text { USP-like protein } \\
\text { isoform } 2\end{array}$ & H9LJ92 & $\begin{array}{l}\text { Crassostrea } \\
\text { ariakensis }\end{array}$ & $\begin{array}{l}6.9 / \\
9.70\end{array}$ & $\begin{array}{l}10.1 / \\
7.97\end{array}$ & 140 & 42 & 3 \\
\hline
\end{tabular}


Table 2. Larval proteins significantly differentially accumulated in response to acidification at both temperatures, warming at both $\mathrm{pHs}$, and the interaction of acidification and warming. Significantly different comparisons with a p-value of $<0.02$ are highlighted.

\begin{tabular}{|c|c|c|c|c|c|c|c|c|c|c|c|}
\hline \multirow{3}{*}{$\begin{array}{l}\text { spo } \\
\mathrm{t} \\
\mathrm{nu} \\
\mathrm{m} .\end{array}$} & \multirow{3}{*}{ Putative protein } & \multicolumn{4}{|c|}{ Effect of reducing $\mathrm{pH}$} & \multicolumn{4}{|c|}{$\begin{array}{c}\text { Effect of increasing } \\
\text { temperature }\end{array}$} & \multirow{2}{*}{\multicolumn{2}{|c|}{$\begin{array}{c}\text { Future } \\
\text { scenario } \\
8.1 / 20 \rightarrow \\
7.9 / 22\end{array}$}} \\
\hline & & \multicolumn{2}{|c|}{$20^{\circ} \mathrm{C}$} & \multicolumn{2}{|c|}{$22^{\circ} \mathrm{C}$} & & & \multicolumn{2}{|c|}{ pH 8.1} & & \\
\hline & & f.c. & $\begin{array}{c}\text { p- } \\
\text { val. }\end{array}$ & f.c. & $\begin{array}{c}\text { p- } \\
\text { val. }\end{array}$ & f.c. & val. & f.c. & $\begin{array}{c}\text { p- } \\
\text { val. }\end{array}$ & f.c. & p-val. \\
\hline \multirow{3}{*}{1} & & 1.7 & 0.00 & 1.7 & 0.09 & & & & 0.79 & 2.0 & \\
\hline & Matrilin-2 & $\searrow$ & 01 & $\searrow$ & 4 & & 0.64 & $1-$ & 6 & $\searrow$ & 0.001 \\
\hline & & 1.2 & 0.24 & 1.1 & 0.61 & 1.2 & 0.41 & 1.5 & & 1.5 & \\
\hline \multirow[t]{2}{*}{2} & GRP78 & $\lambda$ & 2 & $\searrow$ & 3 & $\lambda$ & 3 & $\pi$ & 0.01 & $\lambda$ & 0.051 \\
\hline & & 1.4 & 0.06 & 1 & 0.88 & 1.5 & 0.00 & 1.1 & 0.54 & 1.1 & \\
\hline \multirow[t]{2}{*}{3} & PDI 2 & $\searrow$ & 5 & - & 8 & $\pi$ & 2 & $\lambda$ & 8 & $\pi$ & 0.439 \\
\hline & ATP synthase & & 0.01 & 5.0 & 0.00 & 1.3 & 0.18 & 1.9 & 0.06 & 2.6 & \\
\hline \multirow[t]{2}{*}{4} & subunit $b$ & $2 \searrow$ & 1 & $\searrow$ & 3 & $\searrow$ & 6 & $\lambda$ & 7 & $\downarrow$ & 0.009 \\
\hline & & 1.1 & 0.09 & 1.8 & 0.00 & & 0.94 & 1.6 & 0.00 & 1.1 & \\
\hline \multirow[t]{2}{*}{5} & Severin & $\searrow$ & 8 & $\searrow$ & 5 & $1-$ & 9 & $\nearrow$ & 2 & $\searrow$ & 0.391 \\
\hline & & 1.9 & 0.01 & 1 & 0.73 & 1.6 & 0.05 & 1.1 & 0.12 & 1.2 & \\
\hline \multirow[t]{2}{*}{6} & Severin & $\searrow$ & 4 & - & 9 & $\nearrow$ & 5 & $\searrow$ & 3 & $\searrow$ & 0.154 \\
\hline & & 1.6 & 0.24 & 1.7 & 0.00 & 2.1 & 0.07 & 1.2 & 0.29 & 1.3 & \\
\hline \multirow[t]{2}{*}{7} & Shell matrix protein & $\searrow$ & 2 & $\lambda$ & 1 & $\nearrow$ & 3 & $\searrow$ & 6 & $\nearrow$ & 0.189 \\
\hline & & 1.1 & 0.60 & 1.3 & 0.01 & 1.1 & 0.82 & 1.4 & 0.07 & 1.1 & \\
\hline \multirow[t]{2}{*}{8} & Actin-2 & & 6 & $\searrow$ & 9 & $\searrow$ & 4 & $\pi$ & 5 & $\pi$ & 0.570 \\
\hline & & & 0.12 & 2.6 & 0.04 & 1.7 & 0.05 & 1.1 & 0.77 & 2.6 & \\
\hline \multirow[t]{2}{*}{9} & GAPDH & & 3 & $\searrow$ & 9 & $\searrow$ & 2 & $\searrow$ & 1 & $\searrow$ & 0.008 \\
\hline & & & 0.39 & 1.4 & 0.07 & 1.9 & 0.03 & 1.2 & 0.22 & 1.5 & \\
\hline \multirow[t]{2}{*}{10} & SOD & & 2 & $\nearrow$ & 2 & $\nearrow$ & 9 & $\pi$ & 4 & $\lambda$ & 0.018 \\
\hline & & & 0.04 & 3.5 & 0.01 & 1.7 & 0.08 & 1.3 & 0.23 & 2.8 & \\
\hline \multirow[t]{2}{*}{11} & Vitellogenin-6 & $\lambda$ & 3 & $\lambda$ & 0 & $\pi$ & 2 & $\searrow$ & 3 & $\lambda$ & 0.013 \\
\hline & USP-like protein & 1.2 & 0.45 & 1.6 & 0.09 & & 0.01 & 1.1 & 0.72 & 2.1 & \\
\hline 12 & isoform 2 & $\pi$ & 6 & $\searrow$ & 1 & $2 \searrow$ & 6 & $\searrow$ & 3 & $\searrow$ & 0.010 \\
\hline
\end{tabular}

